\title{
A cross-sectional study about socio-demographic factors and clinical characteristics of male patients with alcohol dependence syndrome
}

\author{
Neeraj J Karandikarl, Pritish Raut ${ }^{2}$, Prasad K Tagad ${ }^{3}$
}

\begin{abstract}
${ }^{1}$ Associate Professor, Department of Psychiatry, DVVPF's Medical College, Ahmednagar, Maharashtra.
${ }^{2}$ Professor, Department of Community Medicine, DVVPF's Medical College, Ahmednagar, Maharashtra.

${ }^{3}$ Assistant Professor, Department of Psychiatry, DVVPF's Medical College, Ahmednagar, Maharashtra.
\end{abstract}

\begin{abstract}
Background: Alcohol abuse is one of the significant causes of death and disability globally; and a key risk factor for health, social, and economic problems in the communities. Consumption of alcohol by Indians has increased drastically due to various factors and in an accessible manner; and the age of initiation of drinking is progressively coming down. Objective: To determine the socio-demographic and clinical profile of the patients coming for treatment of alcohol dependence syndrome in the psychiatry department. Methods: A cross-sectional study was conducted on 50 male outpatients of alcohol dependence syndrome attending the department of psychiatry at a tertiary care hospital. Socio-demographic data and clinical details were recorded with the help of a pre-designed questionnaire. Results: Nuclear family, family history of alcoholism, unmarried status, higher educational level, unemployment, and peer pressure are the factors significantly associated with early age at first drink and age of dependence on alcohol $(p<0.05)$. Conclusion: Those adolescents who had a history of alcoholism in their families were found to be at a higher risk for developing alcohol dependence. Such adolescents can thus be targetted for interventional strategies. Community based-longitudinal studies are needed to understand multiple factors influencing alcohol use and recommend targeted preventive measures.
\end{abstract}

KEYWORDS: Alcohol; Alcohol dependence syndrome; Peer pressure; Intoxication; Socio-demographic factors

\section{INTRODUCTION}

A lcoholism is not a new concept. Globally, siginficant death and disability has been attributed to alcohol abuse. Almost every 1 in 4 individual worldwide consumes some form of alcoholic beverage and a little less than half of such individuals are likely to be diagnosed with alcohol use disorder [1]. Alcohol use has been recognized as a critical risk factor for health, social, and economic problems in the communities [2]. It not only leads to mortality but is a major cause for disability. As ranked by the disability-adjusted life years (DALYs), it is the 5 th leading global risks for the burden of disease. Out of 30\% adult Indians consuming alcohol, $4 \%$ to $13 \%$ consume on a daily basis as reported by The National Family Health Survey (NFHS) [3].

Because of various factors like the impact of globalization, urbanization, industrialization along with media influence and changing lifestyles, consumption of alcohol by Indians has increased drastically and in an accessible manner. Noticeably with passing time the age at which drinking is inititaed is gradually decreasing. Most of the young population of India start this as an experiment with alcohol for pleasureseeking and peer influence, which ultimately end up as habitual users. Another remarkable social influencer of alcohol consumption is the belief that it enhances one's social status. Various

Correspondence: Dr Prasad K Tagad, Assistant Professor, Department of Psychiatry, DVVPF's Medical College, Ahmednagar, Maharashtra. E-mail: drprasad2184@gmail.com

\begin{tabular}{|ll|}
\hline & \\
\hline
\end{tabular}


other factors viz. availability, accessibility, westernization of cultures, marketing strategies etc. have collectively influenced the increased consumption of alcohol [4].

Alcohol abuse and addiction affect health in many ways; it also creates other problems such as social issues, unprotected sex, injuries, violence, road traffic accidents, homicides, suicides, physical dependence, or psychological addiction, deaths.

The study was carried out to determine the socio-demographic and clinical profile of the patients coming for treatment in the psychiatry department. This will help for a better understanding of problems of alcohol use-related factors, which can be prevented with appropriate preventive measures.

\section{Material And Methodology}

\section{Study design: A cross-sectional study}

Ethical approval: Study was approved by the Institutional Ethics Committee of Dr Vithalrao Vikhe Patil Foundation's Vikhe Patil Institute of Medical Sciences vide letter no. DVVPF's VIMS/ IEC/C/2020/6A dated 17/02/2020.

Study location: Study was conducted at the Out-Patient Department of Psychiatry of a Medical College and Hospital.

\section{Study duration: 03 months}

Inclusion criteria: Male patients of age 18 years and above, who fulfil criteria for alcohol dependence syndrome according to ICD-10 DCR, who gave consent were included in the study

Exclusion criteria: Patients with significant physical illness requiring immediate medical/ Surgical management, patients with other substance use disorder except for nicotine.

\section{Sample size: Fifty}

Methodology: The study was conducted on male outpatients of alcohol dependence syndrome attending the department of psychiatry at a tertiary care hospital. All male patients presenting to Psychiatry OPD with alcoholrelated problems were initially evaluated for the study, and only patients fulfilling the inclusion $\&$ exclusion criteria were enrolled into the study. Patients and relatives were given information about the research, and if they were willing, then their written informed consent was taken. Socio-demographic data and clinical details were recorded. The Kuppuswamy socio-economic scale was administered to the patients.(5) The diagnosis of alcohol dependence syndrome was done using ICD-10 Diagnostic Criteria for Research.(6) The results obtained were tabulated, and the statistical analysis was done.

\section{RESUlTs}

A total of 50 male patients of alcohol dependence syndrome attending the de-addiction clinic at a tertiary care hospital were included in the study. Mean age of the participants was 36.22 years $(\mathrm{SD}=8.751)$. Minimum age of the participants was 21 years, and the maximum being 56 years. Out of 50 participants, 35 were from a rural area, 33 were married, and 42 were living in a nuclear family. Most of the patients (66\%) were in class IV of Kuppuswamy's Socio-economic class (Table 1).

Peer pressure (52\%) was the most common Fig 1: Reason for first drink reason for initiation of drinking habit (Fig 1).

Mean age (SD) at first drink was 18.6 years (3.98), for first intoxication 20.06 years (3.622) and for the onset of dependence 25.7 years (4.404) (Table 2). Family conflict (26.67\%) and withdrawal symptoms (24\%) were the main reasons among the participants for seeking treatment (Table 3).

Table 1: Socio-demographic characteristics of the participants

\begin{tabular}{|c|c|c|}
\hline \multicolumn{2}{|c|}{ Socio-demographic variable } & N (\%) \\
\hline \multirow[t]{4}{*}{ Age group } & $20-29$ years & $12(24)$ \\
\hline & $30-39$ years & $20(40)$ \\
\hline & $40-49$ years & $14(28)$ \\
\hline & $50-59$ years & $4(8)$ \\
\hline \multirow{2}{*}{$\begin{array}{l}\text { Area of } \\
\text { residence }\end{array}$} & Rural & $35(70)$ \\
\hline & Urban & $15(30)$ \\
\hline \multirow{3}{*}{$\begin{array}{l}\text { Marital } \\
\text { status }\end{array}$} & Married & $33(66)$ \\
\hline & Unmarried & $11(22)$ \\
\hline & Divorced/Separated & $6(12)$ \\
\hline \multirow[t]{2}{*}{ Family type } & Nuclear & $42(84)$ \\
\hline & Joint & $8(16)$ \\
\hline \multirow[t]{3}{*}{ Education } & Illiterate & $5(10)$ \\
\hline & $\begin{array}{l}\text { Upto Higher } \\
\text { secondary }\end{array}$ & $30(60)$ \\
\hline & $\begin{array}{l}\text { Above higher } \\
\text { secondary }\end{array}$ & $15(30)$ \\
\hline \multirow[t]{3}{*}{ Occupation } & Unemployed & $9(18)$ \\
\hline & $\begin{array}{l}\text { Farmers / Semi \& } \\
\text { Unskilled }\end{array}$ & $38(76)$ \\
\hline & Clerk/Professional & $3(6)$ \\
\hline \multirow{4}{*}{$\begin{array}{l}\text { Socio- } \\
\text { economic } \\
\text { class }\end{array}$} & Class I & $1(2)$ \\
\hline & Class II & $2(4)$ \\
\hline & Class III & $14(28)$ \\
\hline & Class IV & $33(66)$ \\
\hline \multirow{2}{*}{$\begin{array}{l}\text { Family } \\
\text { history of } \\
\text { alcoholism }\end{array}$} & Yes & $26(52)$ \\
\hline & No & $24(48)$ \\
\hline
\end{tabular}


Fig 1: Reason for first drink

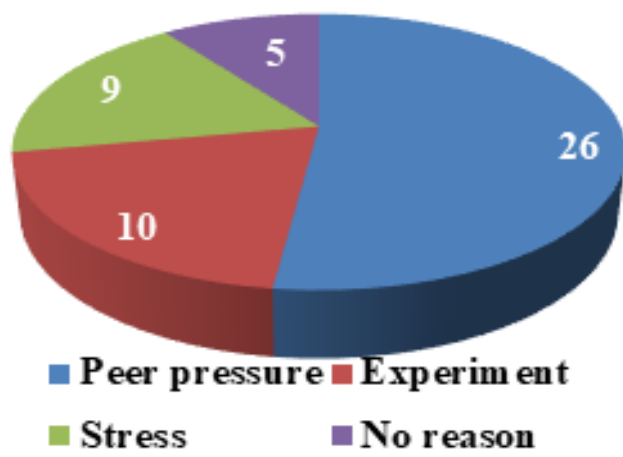

Table 2: Drinking history

\begin{tabular}{|l|l|l|}
\hline & Mean (SD) & $\begin{array}{l}\text { Minimum - } \\
\text { Maximum }\end{array}$ \\
\hline Age at first drink & $18.6(3.98)$ & $15-30$ \\
\hline Age at first intoxication & $20.06(3.62)$ & $15-32$ \\
\hline $\begin{array}{l}\text { Age at onset of } \\
\text { dependence }\end{array}$ & $25.7(4.404)$ & $18-35$ \\
\hline
\end{tabular}

Table 3: Reason for seeking first treatment

\begin{tabular}{|l|c|c|c|c|}
\hline & \multicolumn{3}{|c|}{ Reason (\%) } & Total (\%) \\
\cline { 1 - 4 } & 1 st & 2nd & 3rd & \\
\hline $\begin{array}{l}\text { Family } \\
\text { conflict }\end{array}$ & $21(42)$ & $10(20)$ & $9(18)$ & $40(26.7)$ \\
\hline $\begin{array}{l}\text { Financial } \\
\text { strain }\end{array}$ & $17(34)$ & $6(12)$ & $7(14)$ & $30(20)$ \\
\cline { 1 - 4 } $\begin{array}{l}\text { Physical } \\
\text { health }\end{array}$ & $5(10)$ & $6(12)$ & $\begin{array}{c}12 \\
(24)\end{array}$ & $23(15.3)$ \\
\hline Psychological & $6(12)$ & $6(12)$ & $9(18)$ & $21(14)$ \\
\hline $\begin{array}{l}\text { Withdrawal } \\
\text { symptoms }\end{array}$ & $1(2)$ & $22(44)$ & $\begin{array}{c}13 \\
(26)\end{array}$ & $36(24)$ \\
\hline
\end{tabular}

Nuclear family, family history of alcoholism, unmarried status, higher educational level, unemployment, and peer pressure are the factors significantly associated with early age at first drink and age of dependence on alcohol ( $p<$ 0.05) (Table 4 and 5)

Table 4: Association of various factors with mean age at first drink

\begin{tabular}{|l|l|l|l|l|}
\hline \multicolumn{2}{|c|}{} & N & $\begin{array}{l}\text { Age } \pm \text { SD } \\
\text { at first } \\
\text { drink }\end{array}$ & $\begin{array}{l}\text { p- } \\
\text { value }\end{array}$ \\
\hline \multirow{2}{*}{$\begin{array}{l}\text { Type of } \\
\text { family }\end{array}$} & Nuclear & 42 & $17.8 \pm 2.8$ & 0.001 \\
\cline { 2 - 5 } & Joint & 8 & $22.9 \pm 6.5$ & $* *$ \\
\hline $\begin{array}{l}\text { Family } \\
\text { history of } \\
\text { alcoholism }\end{array}$ & Yes & 26 & $16.7 \pm 2.1$ & $0.000^{*}$ \\
\cline { 2 - 4 } Marital & No & 24 & $20.6 \pm 4.6$ & \\
\cline { 2 - 5 } Status & Married & 33 & $19.5 \pm 4.4$ & $0.027^{*}$ \\
\cline { 2 - 4 } & Sepmarried & 11 & $15.8 \pm 1.1$ & \\
\hline
\end{tabular}

\begin{tabular}{|c|c|c|c|c|}
\hline \multirow{3}{*}{$\begin{array}{l}\text { Education } \\
\text { Level }\end{array}$} & Illiterate & 5 & $25.2 \pm 5.4$ & \multirow{3}{*}{$\begin{array}{l}0.000 \\
* *\end{array}$} \\
\hline & $\begin{array}{l}\text { Upto Higher } \\
\text { secondary }\end{array}$ & 30 & $18 \pm 3.3$ & \\
\hline & $\begin{array}{l}\text { Above } \\
\text { higher } \\
\text { secondary }\end{array}$ & 15 & $17.5 \pm 2.7$ & \\
\hline \multirow{3}{*}{$\begin{array}{l}\text { Type of } \\
\text { occupation }\end{array}$} & Unemployed & 9 & $15.6 \pm 0.9$ & \multirow[t]{3}{*}{$0.03^{*}$} \\
\hline & $\begin{array}{l}\text { Farmers/ } \\
\text { Semi \& } \\
\text { Unskilled }\end{array}$ & 38 & $19.2 \pm 4.1$ & \\
\hline & $\begin{array}{l}\text { Clerk/ } \\
\text { Professional }\end{array}$ & 3 & $20.7 \pm 4.7$ & \\
\hline \multirow{4}{*}{$\begin{array}{l}\text { Reason for } \\
\text { the first } \\
\text { drink }\end{array}$} & $\begin{array}{l}\text { Peer } \\
\text { pressure }\end{array}$ & 26 & $16.7 \pm 1.6$ & \multirow[t]{4}{*}{$\begin{array}{l}0.000 \\
* *\end{array}$} \\
\hline & Experiment & 10 & $17 \pm 2.2$ & \\
\hline & Stress & 9 & $23.8 \pm 4.4$ & \\
\hline & No reason & 5 & $22.6 \pm 4.6$ & \\
\hline
\end{tabular}

Table 5: Association of various factors with mean age of alcohol dependence

\begin{tabular}{|c|c|c|c|c|}
\hline & & $\mathrm{N}$ & $\begin{array}{l}\text { Age } \pm \text { SD } \\
\text { at first } \\
\text { drink }\end{array}$ & $\begin{array}{l}\mathrm{p}- \\
\text { value }\end{array}$ \\
\hline \multirow{2}{*}{$\begin{array}{l}\text { Type of } \\
\text { family }\end{array}$} & Nuclear & 42 & $25.1 \pm 3.8$ & \multirow{2}{*}{$\begin{array}{l}0.019 \\
*\end{array}$} \\
\hline & Joint & 8 & $29 \pm 6$ & \\
\hline \multirow{2}{*}{$\begin{array}{l}\text { Family } \\
\text { history of } \\
\text { alcoholism }\end{array}$} & Yes & 26 & $23.6 \pm 3.1$ & \multirow[t]{2}{*}{$0.000^{*}$} \\
\hline & No & 24 & $28 \pm 4.6$ & \\
\hline \multirow{3}{*}{$\begin{array}{l}\text { Marital } \\
\text { Status }\end{array}$} & Married & 33 & $27.2 \pm 4.1$ & \multirow{3}{*}{$\begin{array}{l}0.000 \\
* *\end{array}$} \\
\hline & Unmarried & 11 & $20.8 \pm 2.4$ & \\
\hline & Separated & 6 & $26.2 \pm 1.3$ & \\
\hline \multirow{3}{*}{$\begin{array}{l}\text { Education } \\
\text { Level }\end{array}$} & Illiterate & 5 & $31 \pm 4.2$ & \multirow[t]{3}{*}{$0.01^{*}$} \\
\hline & $\begin{array}{l}\text { Upto Higher } \\
\text { secondary }\end{array}$ & 30 & $25.5 \pm 4.4$ & \\
\hline & $\begin{array}{l}\text { Above } \\
\text { higher } \\
\text { secondary }\end{array}$ & 15 & $24.3 \pm 3.3$ & \\
\hline \multirow{3}{*}{$\begin{array}{l}\text { Type of } \\
\text { occupation }\end{array}$} & Unemployed & 9 & $21.56 \pm 3$ & \multirow[t]{3}{*}{$0.006^{*}$} \\
\hline & $\begin{array}{l}\text { Farmers/ } \\
\text { Semi \& } \\
\text { Unskilled }\end{array}$ & 38 & $26.6 \pm 4.3$ & \\
\hline & $\begin{array}{l}\text { Clerk/ } \\
\text { Professional }\end{array}$ & 3 & $26.6 \pm 2.9$ & \\
\hline \multirow{4}{*}{$\begin{array}{l}\text { Reason for } \\
\text { the first } \\
\text { drink }\end{array}$} & $\begin{array}{l}\text { Peer } \\
\text { pressure }\end{array}$ & 26 & $23.4 \pm 3.8$ & \multirow[t]{4}{*}{$\begin{array}{l}0.000 \\
* *\end{array}$} \\
\hline & Experiment & 10 & $24.2 \pm 2.9$ & \\
\hline & Stress & 9 & $29 \pm 3.9$ & \\
\hline & No reason & 5 & $32 \pm 4.5$ & \\
\hline
\end{tabular}

\section{Discussion}

The mean age at presentation in our study was $36.22( \pm 8.751)$ years. This finding is consistent with various other studies [7-11]. In Our study, 
$66 \%$ of participants were married at the time of presentation, which matches with other Indian studies where the majority of the study participants are married [7-11]. However, a study from Germany reported a higher number of participants being single or divorced [12]. This difference is probably due to Indian customs, culture and strong marital system.

Most of the patients were from a rural area and living in a nuclear family. This is probably the result of the catchment area of the tertiary care hospital under this study. Similar findings were reported by a previous study [7]. However, it contrasts with a study where most of the patients $(61.67 \%)$ were from an urban background [11]. In our study, out of the total, $60 \%$ of patients had education up to higher secondary level. Similar findings were reported by Dewani K. et al [9] \& Johnson PR et al.[10] Other studies showed lower education status associated with alcohol dependence [7-8].

In our study, $82 \%$ of the patients were employed in unskilled or semiskilled work. Similar to our findings other studies have reported a higher percentage of participants involving in work not requiring much education or skills [7-9,11]. However, Johnson PR et al. [10] \& Vignesh BT et al.[13] found a higher number of participants involved in skilled, professional jobs.

Like our study, Reddy MP et al.[7] \& Mukhopadhyay $\mathrm{J}$ et al. [11] reported that the majority of patients belonged to the lower middle class as per Kuppuswamy's scale. In a study by Sarkar AP et al.[8] majority of patients were in class II, according to Modified B. G. Prasad's scale for socio-economic status.

Mean age at which first drink of alcohol (in any form or amount) taken was 18.6 years. The mean age at getting intoxicated by the alcohol for the first time was 20.06 years. A study with similar design reported the mean age at first use of alcohol 18.9 years and at intoxication to be 19.8 years [7]. In another study, the mean age of first drink of alcohol was found to be 23.6 years. A multicentric study from Germany reported a mean age at first drink as 15.4 years \& age at first intoxication as 17.82 years [12]. Other studies have found late age of onset of drinking $\&$ first intoxication $[9,10]$. Our study found earlier age for onset of dependence (25.7 years) as compared to previous studies $[7,10,11]$.

The main reason for the initiation of alcohol use was peer pressure, followed by curiosity (Graph 1). Similar findings were reported by Merchant $H$ et al. [14]. In another study, the influence of an alcoholic father (51.67\%) and feeling low at the loss of job $(11.67 \%)$ were recounted to be two major reasons [11].
In our study, patients were asked about reasons for seeking current treatment. Based on the various reasons reported by patients, these could be grouped into certain categories. Family conflict $(26.67 \%)$ and withdrawal symptoms $(24 \%)$ were the main reasons among the participants for seeking treatment (Table 3). A study by Reddy MP et al. [7] reported that financial strain due to alcohol use and family conflict were the most common reasons for seeking treatment. Similar reasons have been recognized in other studies, also [11]. In another study, 98\% of individuals seek care due to withdrawal symptoms such as delirium tremens or withdrawal seizures [9].

In our study, nuclear family, family history of alcoholism, unmarried status, higher educational level, unemployment and peer pressure are the factors significantly associated with early age at first drink and age of dependence on alcohol $(\mathrm{p}<$ 0.05) (Table 4 and 5)

Our findings corroborate with other studies who found that the risk for early initiation of alcohol consumption is higher in individuals with a family history of alcohol when compared to their counterparts with no alcohol use history in the family $[8,15,16]$. However, in another study, the results showed no remarkable difference in alcohol consumption and drinking patterns between students with or without a family history of alcoholism [17].

However, unlike our study, previous studies have not found a significant association between family type, residence, educational status, marital status, and occupational status with alcoholism [8, 13].

\section{Conclusion}

Early age of first use of alcohol significantly increases the chances of progression to the development of alcohol dependence. Therefore, adolescents who have a positive family history of alcoholism should be treated as a high-risk group for developing alcohol dependence and should be targeted for intervention strategies. Educational programs for school children and campaign for the public to make them aware of the harmful effects of alcohol use are needed to control the alcohol use-related problems. Further, community based-longitudinal studies are needed to understand multiple factors influencing alcohol use and recommend targeted preventive measures.

\section{Conflict of interest : Nil Source of funding : Nil REFERENCES}

1. Global status report on alcohol. Geneva: World Health Organization; 2004.

2. World Health Organization (WHO). Global 
health risks: Mortality and burden of disease attributable to selected major risks. Geneva, Switzerland: 2009.

3. Ministry of Health and Family Welfare. National Family Health Survey (NFHS III). New Delhi: Government of India; 2015-16

4. Gururaj G, Murthy P, Girish N, Benegal V. Alcohol related harm: Implications for public health and policy in India, Publication No. 73. Bangalore, India: National Institute of Mental Health and Neuro Sciences. 2011; 11-16,30.

5. Kuppuswamy, B, 1981. Manual of Socioeconomic status (Urban) Delhi: Manasayan.

6. World Health Organization, 1993.The ICD10 Classification of Mental and Behavioural Disorders: Diagnostic Criteria for Research. In. Geneva: World Health Organization.

7. Reddy MP, Babu RS, Pathak SM, Venkateshwarlu S. The clinical and demographic profile of male patients with alcohol dependence syndrome. Indian journal of psychological medicine. 2014 Oct;36(4):418.

8. Sarkar AP, Sen S, Mondal S, Singh OP, Chakraborty A, Swaika B. A study on sociodemographic characteristics of alcoholics attending the de-addiction center at Burdwan medical college and hospital in West Bengal. Indian journal of public health. 2013 Jan $1 ; 57(1): 33$

9. Dewani K, Mutalik NR, Choudhari SB. Clinical and Socio-demographic Profile of Patients with Alcohol Dependence Syndrome: A Hospital Based Study. Psychiatry and Mental Health. 2017 July-December; $1(2): 61-65$

10. Johnson PR, Banu S, Ashok MV. Severity of alcoholism in Indian males: Correlation with age of onset and family history of alcoholism. Indian journal of psychiatry. 2010 Jul;52(3):243.

11. Mukhopadhyay J. Medico-social profile of male alcoholics in a north Indian city. InternationalJournal of Community Medicine and Public Health. 2017 Jul;4(7):2596

12. Schneider U, Altmann A, Baumann M, Bernzen J, Bertz B, Bimber U, Broese T, Broocks A, Burtscheidt W, Cimander KF, Degkwitz P. Comorbid anxiety and affective disorder in alcohol-dependent patients seeking treatment: the first Multicentre Study in Germany. Alcohol and alcoholism. 2001 May 1;36(3):219-23.
S, Joshi A. Association between sociodemographics and alcohol dependence among individuals living in an Indian setting. Global journal of health science. 2014 May;6(3):16.

14. Merchant H, Pandya P. Cultural determinants responsible for development of alcohol dependence - a cross-sectional observational hospital-based study. International Journal of Interdisciplinary and Multidisciplinary Studies. 2015 Feb; 2(4): 161-172

15. Chopra A, Dhawan A, Sethi H, Mohan D. Association between parental and offspring's alcohol use--population data from India. Journal of Indian Association for Child and Adolescent Mental Health. 2008;4(2):38-43

16. Hill SY, Yuan H. Familial density of alcoholism and onset of adolescent drinking. Journal of Studies on Alcohol. 1999 Jan;60(1):7-17.

17. Engs RC. Family background of alcohol abuse and its relationship to alcohol consumption among college students: an unexpected finding. Journal of Studies on Alcohol. 1990 Nov;51(6):542-7. 